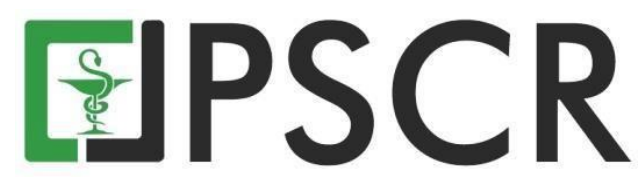

\title{
Pengaruh Perbandingan Tween 80 dan Fosfatidilkolin Pada Formulasi Transfersom Naringenin dan Kajian Permeasi Berbasis Hidrogel
}

\author{
Ilham Kuncahyo*, Juniar Kalpika Resmi dan M. Muchalal \\ Program Studi S1 Farmasi, Universitas Setia Budi, Jl. Letjen Sutoyo Mojosongo, Surakarta, Indonesia, 57127. \\ *email korespondensi: ilhamninda@gmail.com \\ Received 28 April 2021, Accepted 06 October 2021, Published 15 November 2021
}

\begin{abstract}
Abstrak: Naringenin merupakan flavonoid isolat kulit buah jeruk yang mempunyai kelarutan yang rendah. Potensi naringenin dalam terapi dermatitis atopik pada sistem penghantaran transfersom dapat meningkatkan kemampuan naringenin dalam berpenetrasi ke dalam kulit sehingga mampu mengefektifkan proses penyembuhan. Penelitian ini bertujuan untuk mengkaji pengaruh perbandingan molar fosfatidilkolin sebagai pembentuk vesikel dan Tween 80 yang berfungsi sebagai surfaktan terhadap karakteristik transfersom naringenin dan mengetahui permeasi narigenin terinkorporasi dalam trasfersom berbasis hidrogel. Formula dibuat menjadi 4 untuk diaplikasikan pada proses pembuatan transfersom naringenin dengan variasi perbandingan molar fosfatidilkolin dan Tween 80 yaitu 97,5:2,5 (FI), 90:10 (FII), 85:15 (FIII), dan 80:20 (FIV) menggunakan teknik evaporation-ultrasonication. Hasil transfersom naringenin masing-masing formula dilakukan karakterisasi terhadap ukuran partikel, indeks polidispersi, dan efisiensi penjerapan. Formula transfersom terpilih diformulasikan dalam sediaan gel dan dilakukan uji permease menggunakan membran selofan (WMCO 8 kDa). Hasil penelitian menunjukkan bahwa peningkatan jumlah surfaktan akan menurunkan ukuran partikel dan peningkatan jumlah fosfatidilkolin akan meningkatkan jumlah obat yang terjerap. Formula dengan perbandingan Phospholipon 90G: Tween 80 (85:15, F3) merupakan formula terpilih dengan ukuran dan indeks polidispersi partikel masing-masing 115,6 nm dan 0,274 serta efisiensi penjerapan sebesar $88,63 \pm 0,59 \%$. Sediaan gel naringenin transfersom memberikan nilai jumlah kumulatif dan laju penetrasi yang besar dibandingkan gel naringenin tanpa transfersom.
\end{abstract}

Kata kunci: fosfatidilkolin; gel; naringenin; transfersom; tween 80

Abstract. The effect of Tween 80 to phosphatidylcholine ratio on the characteristics of narigenin-based transfersome and permeation study hydrogel-based formulation. Naringenin is a flavonoid that has potential in the treatment of atopic dermatitis. Due to low oral solubility and absorption, topical route is more preferable. Topical administration of naringenin loaded-transfersome system offers more optimal therapeutic effect in the terapy atopic dermatitis. This study aimed to determine the optimized formulation of naringenin-based transfersome through various concentration of phosphatidylcholine and Tween 80. Naringenin transfersome was prepared 4 formulations along with different of phosphatidylcholine to Tween 80 molar ratios namely 97,5:2,5, 90:10, 85:15, and 80:20 for formulation FI, FII, FIII, and FIV, respectively. Evaporation-sonication method was applied for transfersome preparation followed by characterization e.g., particle size, polydispersity index, and entrapment efficiency. Selected transfersome formulation was incorporated into hydrogel formulation and further evaluation was carried out by permeation testing. The result showed that FIII (85: 15) had the optimized characteristics of transfersome naringenin along with particle size, polydispersity index, and entrapment efficiency of $115,6 \mathrm{~nm}, 0.274$, and 88,63 $\pm 0,59 \%$, respectively. 
Transfersome naringenin gel preparation had higher cumulative permeated narigenin and it was seven time higher than that of hydrogel narigenin without transfersome.

Keywords: phosphatidylcholine; gel; naringenin; transfersome; tween 80

\section{Pendahuluan}

Naringenin banyak terkandung dalam kulit buah jeruk yang digunakan untuk antioksidan, antifotoprotektif, dan anti inflamasi (Pannu et al., 2019; Nagula \& Wairkar, 2020). Potensi naringenin yang merupakan suatu senyawa flavonoid dengan kelarutan rendah dapat dikembangkan menjadi sediaan topikal untuk pengobatan gangguan kulit seperti dermatitis atopik (DA) (Pannu et al, 2019). Naringenin termasuk dalam biopharmaceutical classification system kelas II dengan kelarutan rendah dan permeabilitas tinggi yang ditunjukkan dengan sifat lipofilisitas berdasarkan nilai koefisien partisinya 2,6 (Salehi et al., 2019). Absorbsi naringenin secara per oral menunjukkan keterbatasan bioavaibilitas yang rendah yaitu $15 \%$ disebabkan rendahnya kelarutan narigenin dan permasalahan efflux transporter dari narigenin (Joshi et al., 2018). Srategi modifikasi sistem penghantaran obat dan sediaan perlu dilakukan pada narigenin utamanya untuk terapi DA melalui penghantaran secara perkutan.

Transport obat secara topikal dirancang untuk menghantarkan komponen bioaktif ke target terapetik. Sistem penghantaran obat dapat dilakukan dengan memodifikasi formulasi berbasis polimer menggunakan kitosan dengan metode gelasi ionik maupun dengan berbasis lipid (Fitri et al., 2020). Modifikasi sistem penghantaran formulasi berbasis lipid memberikan keuntungan yang lebih terkait dengan sistem penghantaran obat secara perkutan. Permasalahan utama yang terjadi adalah adanya barrier secara fisik baik dari stratum korneum dan struktur kulit yang menghangi transport obat secara perkutan. Formulasi berbasis lipid seperti nanoemulsi, solid lipid nanopartikel, dan nanostructured lipid carrier diaplikasikan untuk meningkatkan penghantaran obat secara perkutan. Pengaruh panjang rantai karbon lipid pada nanostructured lipid carrier resveratrol dilaporkan mempengaruhi terhadap proses penghantaran obatnya (Aisiyah et al., 2019). Akan tetapi, beberapa sistem penghataran tersebut tidak menunjukkan karakteristik permasi yang optimal disebabkan karena bentuk dan karakteristik dari pembawa. Modifikasi sediaan dalam bentuk sistem penghantaran menggunakan sistem vesikel seperti liposom, transfersom serta ethosom telah dilaporkan mampu meningkatkan kemampuan obat berpenetrasi ke dalam kulit (Choi \& Maibach, 2005).

Pemilihan sistem transfersom lebih menguntungkan dibandingkan sistem liposom karena mampu berpenetrasi ke dalam kulit dengan pori yang lebih kecil. Kemampuan ini disebabkan sistem transfersom deformabilitasnya lebih besar dibandingkan liposom (Walve et al., 2011). Komponen pembentuk transfersom yang meliputi Tween 80 sebagai surfaktan dan 
fosfatidilkolin sebagai sistem vesikel akan mempengaruhi karakteristik dari sistem transfersom utamanya sifat deformabilitas. Penelitian sebelumnya menunjukkan bahwa sistem transfersom asam askorbat memberikan hasil karakteristik yang berbeda seperti efisiensi penjerapan, ukuran partikel, dan morfologi sistem vesikel dengan berbagai kombinasi Tween 80 dan fosfatidilkolin (Ismail et al., 2018). Pembuatan dalam sediaan gel transfersom yang mengandung bahan aktif kojyl 3 amino propil fosfat dibandingkan dengan gel tanpa transfersom memberikan hasil peningkatan terhadap kecepatan dan daya difusi dalam menembus kulit (Andini et al., 2016). Peningkatan disebabkan adanya surfaktan (Tween 80) dan bahan pembentuk vesikel (fosfatidilkolin) dalam sistem transfersom akan meningkatkan deformabilitas dan lipofilitas sehingga meningkatkan kemampuan penetrasinya ke kulit. Surfaktan dan pembentuk vesikel memiliki peranan yang dominan dalam menentukan karakteristik akhir dari sistem transfersom. Formulasi naringenin dalam sistem penghantaran berbasis transfersom terinkorporasi dalam sediaan pembawa hidrogel belum pernah dilaporkan. Keterkaitan sifat fisikokimia naringenin dan keterbatasannya dalam penggunaan secara per oral menjadi latar belakang perlunya dilakukan pembuatan sediaan topikal bentuk nanotransfersom berbasis gel untuk meningkatkan permeasi. Penelitian ini bertujuan untuk mengetahui pengaruh variasi Tween 80 dan fosfatidilkolin dalam membentuk sistem transfersom naringenin. Pengamatan dilakukan dengan uji karakterisasi terhadap ukuran partikel, indek polidispersi dan efisensi penjerapannya, dilanjutkan dengan pembuatan sediaan gel dari komponen sistem transfersom naringenin terbaik dan dilakukan kajian secara in vitro untuk mengetahui kemampuan difusinya menggunakan uji difusi Franz.

\section{Bahan dan Metode}

\subsection{Bahan}

Bahan aktif naringenin diperoleh dari Thanen Chemical (Changzhou, China). Komponen transfersom yaitu Tween 80 dan Phospholipon 90G yang diperoleh dari Sigma Aldrich (St. Louis, MO) dan Lipoid GmbH (Koln, Jerman). Reagensia dan pelarut antara lain methanol, natrium hidroksida, kalium dihidrogen fosfat yang diperoleh dari Merck (Darmstadt, Jerman) serta kloroform yang diperoleh dari Smart-Lab (Jakarta, Indonesia). Carbopol 934 diperoleh dari The Lubrizol Corporation (Jakarta, Indonesia). Trietanolamin dan air diperoleh dari pemasok lokal (Bratachem; Surakarta, Indonesia).

\subsection{Pembuatan sistem transfersom naringenin}

Penelitian dilakukan dengan 4 formula yang masing-masing formula transfersom perbandingan molarnya Phospoliphon 90G dan Tween 80 berbeda, yaitu 97,5:2,5 Formula I (FI); 90:10 Formula II (FII); 85:15 Formula III (FIII), dan 80:20 Formula IV (FIV). Jumlah 
bahan aktif naringenin dibandingkan vesikel (phospholipon 90G + Tween 80) dibuat 1:5 (El Zaafarany et al., 2010). Desain dan rancangan formula transfersom naringenin dapat dilihat di Tabel 1.

Bahan aktif naringenin dan komponen transfersom (Phospholipon 90G dan Tween 80) masing-masing formula dimasukkan dalam labu alas bulat (LAB), kemudian dilarutkan dengan penambahan pelarut campuran organik metanol:kloroform perbandingan 1:1 sebanyak $10 \mathrm{~mL}$. Larutan yang terbentuk dilakukan proses penguapan pelarut dengan diputar menggunakan evaporator (IKA, Jerman) yang diputar dengan kecepatan $60 \mathrm{rpm}$ dengan suhu penguapan $50^{\circ} \mathrm{C}$ sampai terbentuk lapisan tipis pada dinding LAB. Tahap selanjutnya dilakukan proses hidrasi dengan menambahkan $20 \mathrm{~mL}$ larutan dapar phospat $\mathrm{pH}$ 7,4. LAB diputar sampai terbentuk koloid yang homogen dan diamkan selama 60 menit kemudian dilakukan proses pengecilan ukuran partikel dengan alat sonikator ultrasonik (Heidolph; Schwabach, Jerman) yang diatur dengan kekuatan amplitude 50\% dalam waktu 10 menit. Tranfersom naringenin yang diperoleh masing-masing formula disimpan dan dilakukan karakterisasi. Parameter karakterisasi yang meliputi ukuran partikel, indek polidispersi, dan efisiensi penjerapan dijadikan parameter untuk memilih formula transfersom naringenin terbaik. Formula terpilih dibuat sediaan gel transfersom naringenin.

Tabel 1. Desain dan rancangan formula transfersom narigenin.

\begin{tabular}{ccccc}
\hline Komposisi & Formula & Formula & Formula & Formula \\
& I & II & III & IV \\
\hline Naringenin $(\mathrm{mg})$ & 400 & 400 & 400 & 400 \\
Phospholipon 90G $(\mathrm{mg})$ & 1950 & 1800 & 1700 & 1600 \\
Tween 80 (mg) & 50 & 200 & 300 & 400 \\
Buffer fosfat pH 7,4 (mL) & 20 & 20 & 20 & 20 \\
\hline
\end{tabular}

\subsection{Penetapan distribusi dan ukuran partikel}

Pengamatan terhadap ukuran globul dan indek polidisperi transfersom naringenin dengan alat particle size analyzer (PSA) (Malvern, UK) dengan metode penghamburan cahaya. Sampel dimasukkan ke dalam kuvet kuarsa dan diukur ukuran partikelnya pada panjang gelombang 633 $\mathrm{nm}$ dengan indeks bias 1,333 dan sudut $173^{\circ}$ pada suhu $25^{\circ} \mathrm{C}$. Nilai z-average dan polydispersity indeks digunakan untuk menyetakan ukuran partikel dan distribusi dari ukuran partikel transfersom narigenin.

\subsection{Efisiensi penjerapan}

Jumlah obat yang terjerap dan yang tidak terjerap diukur dengan menghitung efisiensi penjerapan. Langkah awal dilakukan proses sentrifugasi (PLC Series; Taiwan) selama 60 menit dengan kecepatan $6000 \mathrm{rpm}$ terhadap masing-masing koloid transfersom naringenin. Supernatan yang berwarna jernih hasil sentrifugasi dihitung kadar obatnya menggunakan 
spektrofotometer UV-Vis yang sudah dilakukan validasi $\left(\mathrm{R}^{2}=0,99\right.$; presisi dengan nilai $\mathrm{RSD}$ 0,85\%, akurasi 99,90\%, LOD dan LOQ masing-masing 1,48 dan 4,50 $\mu \mathrm{g} / \mathrm{mL}$ ). Efisiensi penjerapan (EP) dinyatakan dengan persentase selisih jumlah obat yang dimasukkan dalam sistem transfersom (LTO) dengan jumlah obat bebas dalam supernatant (OB) (Persamaan 1).

$$
\% E P=\frac{T D-F D}{T D} \times 100 \%
$$

Persamaan 1. Efisiensi penjerapan. Keterangan: $\mathrm{TD}=$ total senyawa yang terdapat dalam formula; $\mathrm{FD}=$ jumlah senyawa yang terdapat dalam supernatan (tidak terjerap).

\subsection{Pembuatan sediaan gel}

Formula hydrogel transfersom disajikan pada Tabel 2. Carbopol 934 digunakan sebagai basis hydrogel yang diaplikasikan untuk menginkorporasikan transfersom narigenin. Carbopol 934 dikembangkan dan dihidrasi dalam air panas sebanyak $20 \mathrm{~mL}$. Trietanolamin ditambahkan kemudian didiamkan sampai 24 jam. Basis gel dihomogenkan dengan homogenizer selama 30 menit dengan kecepatan $500 \mathrm{rpm}$. Formula terbaik transfersom naringenin ditambahkan propilenglikol kemudian dimasukkan ke dalam basis gel, diaduk sampai homogen. Hidrogel yang terbentuk disimpan pada suhu dan kondisi ruang sampai dilakukan proses pengujian transport narigenin.

Tabel 2. Formula sediaan gel transfersom naringenin dan gel naringenin tanpa transfersom. Keterangan: Formula gel diambil dari naringenin transfersom dengan formula yang terbaik.

\begin{tabular}{ccc}
\hline Bahan & F-A $(\boldsymbol{\%})$ & F-B (\%) \\
\hline Naringenin (Transfersom) & 2 & - \\
Naringenin & - & 2 \\
Carbopol-934 & 0,81 & 0,81 \\
Propilenglikol & 5,9 & 5,9 \\
Trietanolamin & 0,58 & 0,58 \\
Aquadestilata & $a d 100$ & $a d 100$ \\
\hline
\end{tabular}

\subsection{Uji penetrasi sediaan gel secara in-vitro menggunakan sel difusi Franz}

Kemampuan difusi sediaan gel transfersom naringenin dan sediaan gel naringenin diukur menggunakan alat Franz diffusion cell menggunakan membran selofan pori $250 \mathrm{~nm}$ (MWCO $8 \mathrm{kDa}$, Cellu-Sep T2 dialysis membran) dengan luas membran $5,77 \mathrm{~cm}^{2}$; volume kompartemen yang berisi dapar fosfat $\mathrm{pH} 7,4$ sebanyak $15 \mathrm{~mL}$ dan suhu percobaan $32^{\circ} \mathrm{C}$. Masing-masing sediaan gel ditimbang sebanyak $2 \mathrm{~g}$ dan dioleskan secara merata pada permukaan membran selofan. Pengukuran terhadap lepasnya obat dalam sediaan gel diamati dengan pengambilan sampling sebanyak 2,0 mL yang diambil pada menit ke 5, 10, 15, 30, 45, 60, dan 90. Setiap pengambilan sampling maka ditambahkan larutan dapar phospat sebanyak $2 \mathrm{~mL}$. Kadar naringenin yang terpermeasi dihitung berdasarkan serapan yang dibaca menggunakan 
spektrofotometri UV-Vis pada panjang gelombang maksimum naringenin. Jumlah kumulatif naringenin terpenetrasi dan fluks penetrasi naringenin dapat dihitung berdasarkan Persamaan 2 dan Persamaan 3.

$$
\mathrm{Q}=\frac{\left((C n \cdot V)+\left(\sum_{i=1}^{n-1} C . S\right)\right)}{A}
$$

Persamaan 2. Jumlah kumulatif naringenin yang terpenetrasi. Keterangan: $\mathrm{Cn}=$ konsentrasi naringenin $(\mu \mathrm{g} / \mathrm{mL})$ pada sampling menit ke-n; V = volume sel difusi Franz $(\mathrm{mL}) ; \sum_{i=1}^{n-1} C=$ konsentrasi terpenetrasi pada menit sebelumnya; $\mathrm{S}=$ volume sampling $(\mathrm{mL}) ; \mathrm{A}=$ Luas membrane $\left(\mathrm{cm}^{2}\right)$.

\subsection{Analisis hasil}

Analisa data secara statistik menggunakan signifikansinya 95\% $(p=0,05)$. Kemampuan difusi sediaan gel dilakukan dengan dibuat grafik antara waktu dan jumlah obah terpenetrasi dari data masing-masing formula. Nilai fluk dihitung berdasarkan kemiringan dari regresi linear yang dihasilkan (Persamaan 3).

$$
\mathrm{J}=\frac{M}{(S \times t)}
$$

Persamaan 3. Fluks penetrasi naringenin. Keterangan: $J=$ Fluks $\left(\mu \mathrm{g} \cdot \mathrm{cm}^{-2} \cdot \mathrm{jam}^{-1}\right) ; \mathrm{M}=$ jumlah kumulatif naringenin yang melalui membran $(\mu \mathrm{g}) ; \mathrm{S}=$ luas membran difusi $\left(\mathrm{cm}^{2}\right) ; \mathrm{t}=$ waktu $($ jam $)$.

\section{Hasil dan Pembahasan}

\subsection{Pembuatan naringenin dalam sistem transfersom}

Pembuatan naringenin dalam sistem transfersom dibuat 4 formula yang masing-masing formula dibuat dengan perbandingan molar fosfatidilkolin dan Tween 80 yang berbeda. Formula I perbandingannya 97,5: 2,5, formula II 90:10, formula III 85:15, dan formula IV 80:20. Perbedaan jumlah perbandingan komponen transfersom akan memberikan hasil karakteristik seperti ukuran partikel, indek polidispersi dan efisiensi penjerapan yang berbeda.

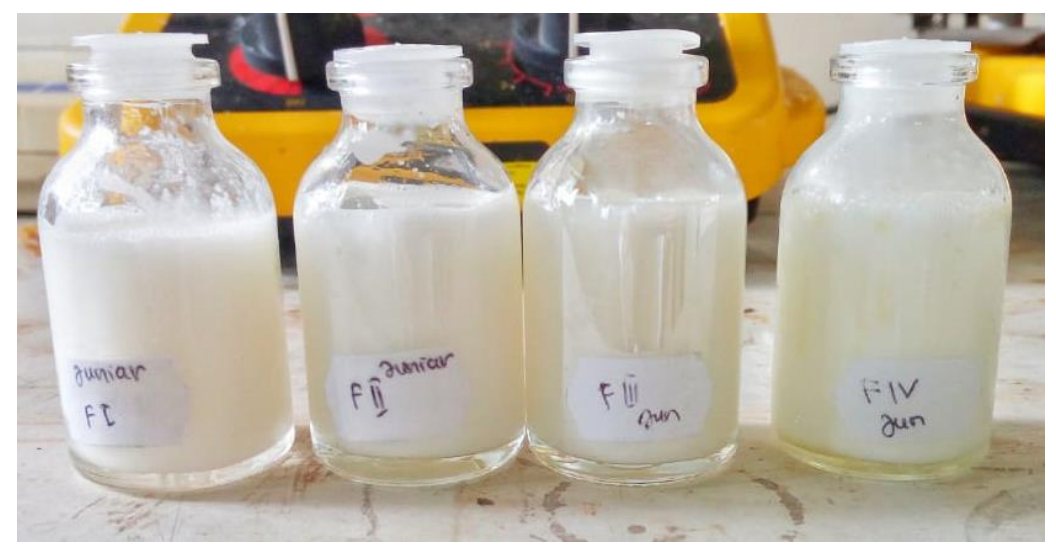

Gambar 1. Transfersom narigenin yang terbentuk berdasarkan perbedaan rasio molar fosfolipid dan surfaktan. F1 (92,5:7,5), FII (90:10); FIII (85:15), dan FIV (80:20).

Pemilihan metode kombinasi evaporation-sonication atau hidrasi lapis tipis dalam pembuatan transfersom naringenin karena memberikan kadar efisiensi obat yang terjerap lebih 
besar, lapisan lipid yang terbentuk pada dinding LAB mempunyai luas permukaan yang besar sehingga akan meningkatkan efisensi proses hidrasi dibandingkan metode vortexing-sonication (El Zaafarany et al., 2010). Hasil koloid masing-masing formula transerfom naringenin dapat dilihat pada Gambar 1. Hasil menunjukkan bahwa FI dengan jumlah fosfolipid paling besar memberikan penampilan warna putih susu dengan intensitas yang meningkat, sedangkan menurunnya jumlah fosfolipid dalam F IV memberikan warna yang pudar dibandingkan dengan formula lainnya.

\subsection{Karakterisasi vesikel transfersom}

\subsubsection{Ukuran partikel dan indeks polidispersi}

Ukuran partikel dan indeks polidispersi ukuran partikel transfersom naringenin dipengaruhi oleh perbedaan dari jumlah perbandingan molar antara fosfatidilkolin dan Tween 80. Pengukuran digunakan alat particle size analyzer (PSA) dengan prinsip dynamic light scattering (DLS). Hasil ukuran partikel dan indeks polidispersitas dapat dilihat pada Gambar 2.

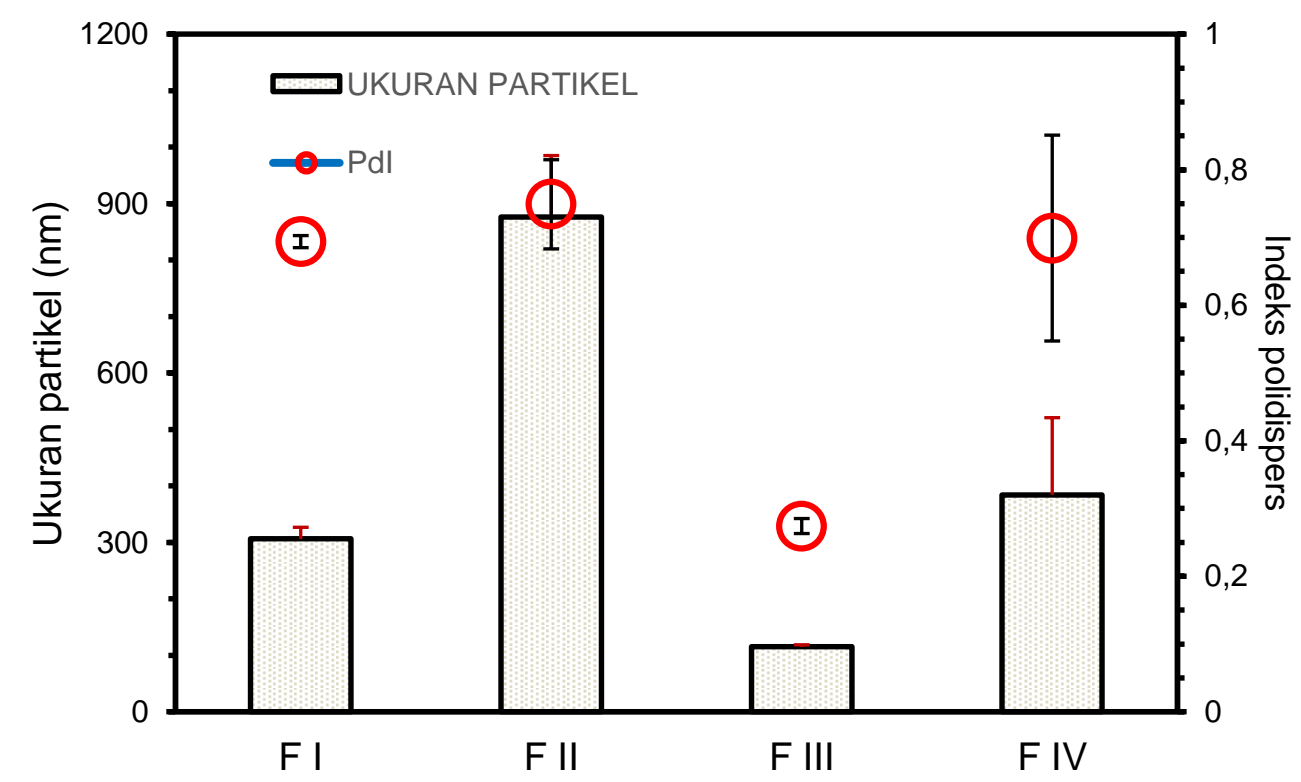

Gambar 2. Pengaruh rasio molar fosfolipid dan surfaktan terhadap ukuran partikel dan indeks polidispersitas (PdI). F1 (92,5:7,5), FII (90:10); FIII (85:15), dan FIV (80:20).

Gambar 2 menunjukkan bahwa ukuran partikel yang paling kecil adalah FIII, diikuti FI, FIV, dan FII. Semakin meningkat jumlah fosfatidilkolin maka memperbesar ukuran partikel sedangkan meningkatnya jumlah Tween 80 akan memperkecil ukuran partikel transfersom (Saraf et al., 2011). Kemampuan surfaktan dalam memperkecil ukuran partikel ini meningkatkan proses perpindahan surfaktan dari lingkungan yang lipofil ke lingkungan air sehingga terbentuk sistem nanoemulsi (Hasani et al., 2015). Dari hasil penelitian dengan meningkatnya jumlah surfaktan dari FI (97,5:2,5), FII (90:10) hingga FIII (85:15) memberikan hasil ukuran partikel yang semakin kecil. FIV dengan perbandingan fosfatidilkolin dan Tween 
80 (80:20) dibandingkan FIII (85:15) menghasilkan ukuran partikel yang meningkat. Pola yang tidak teratur ini dimungkinkan adanya interaksi antar bahan pada perbedaan stoikiometri mol mungkin menyebabkan anomali pola pada ukuran partikel, studi lebih lanjut dapat dilakukan untuk kajian yang lebih terintegrasi dan sistematis. Kemampuan penetrasi sistem transfersom ditentukan oleh ukuran partikel dan sifat deformabilitas (Choi \& Maibach, 2005), sehingga FIII memberikan hasil yang paling baik dibandingkan beberapa formula lainnya. Cevc \& Blume (1992) menyatakan bahwa sistem transfersom dengan ukuran partikel di bawah $300 \mathrm{~nm}$ akan memberikan kemampuan penetrasi yang baik dan deformabilitias yang lebih baik dibandingkan sistem vesikuler menggunakan liposom.

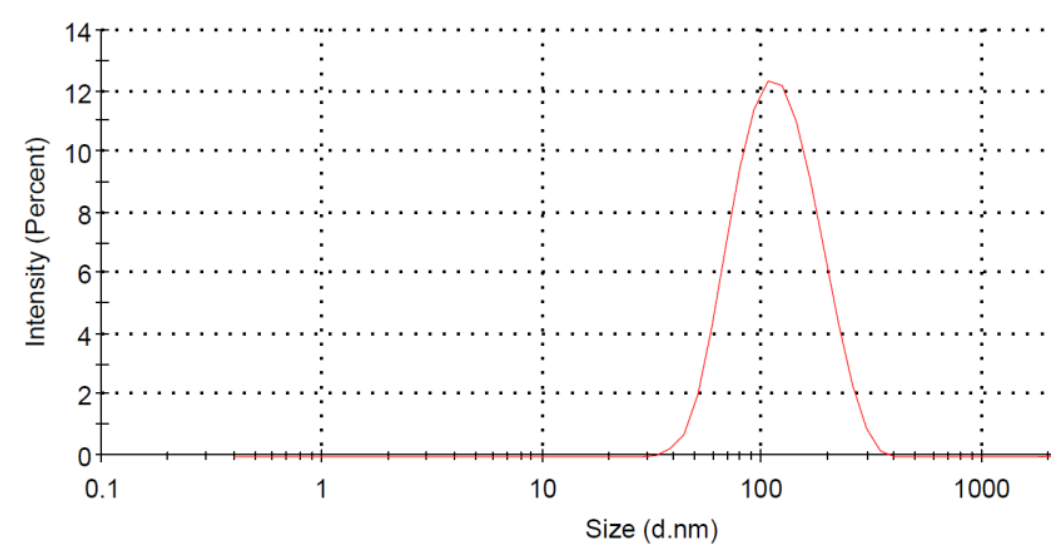

Gambar 3. Distribusi ukuran partikel transfersom naringenin narigenin pada formula III.

Indeks polidispersi (PdI) menggambarkan kehomogenan ukuran partikel dari transfersom naringenin. Hasil PdI yang kurang dari 0,5 dan cenderung mendekati nilai 0 akan menggambarkan bahwa rentang dan ukuran partikel homogen (Shilakari et al., 2013). FIII memeberikan PdI sebesar 0,274 yang lebih baik dibandingkan dengan FI $(0,694)$, FII $(0,749)$, dan FIV (0,829). Distribusi partikel transfersom formula III yang dilihat pada Gambar 3 menunjukkan transfersom yang dihasilkan merupakan sistem dispersi yang monodisperse dengan lebar distribusi yang relatif sempit.

\subsubsection{Efisiensi penjerapan}

Efisiensi penjerapan dinyatakan dalam persen obat yang terjerap dalam matriks lipid terhadap obat yang ditambahkan (Parhi \& Suresh, 2010). Hasil efisiensi penjerapan keempat formula yang disajikan pada Gambar 4 yang menunjukkan nilai efisien penjerapan antara 66,34 $-95,17 \%$. Nilai efisiensi penjerapan paling besar ditunjukkan pada FII, kemudian FI, FIII dan FIV. Jumlah fosfatidilkolin yang semakin meningkat akan meningkatkan jumlah vesikel yang berfungsi untuk menjerap naringenin semakin besar masuk dalam sistem tersebut. Hasil uji statistik terhadap efisiensi penjerapan keempat formula menunjukkan tidak ada perbedaan bermakna antara formula $(p>0,05)$. Dengan demikian FIII dipilih sebagai formula transfersom 
naringenin yang akan diinkorporasikan ke dalam hidrogel didasarkan atas ukuran partikel yang paling kecil yaitu 115,6 nm dibandingkan FI (306,4 nm), FII (876,6 nm) dan FIV (384,1 nm).

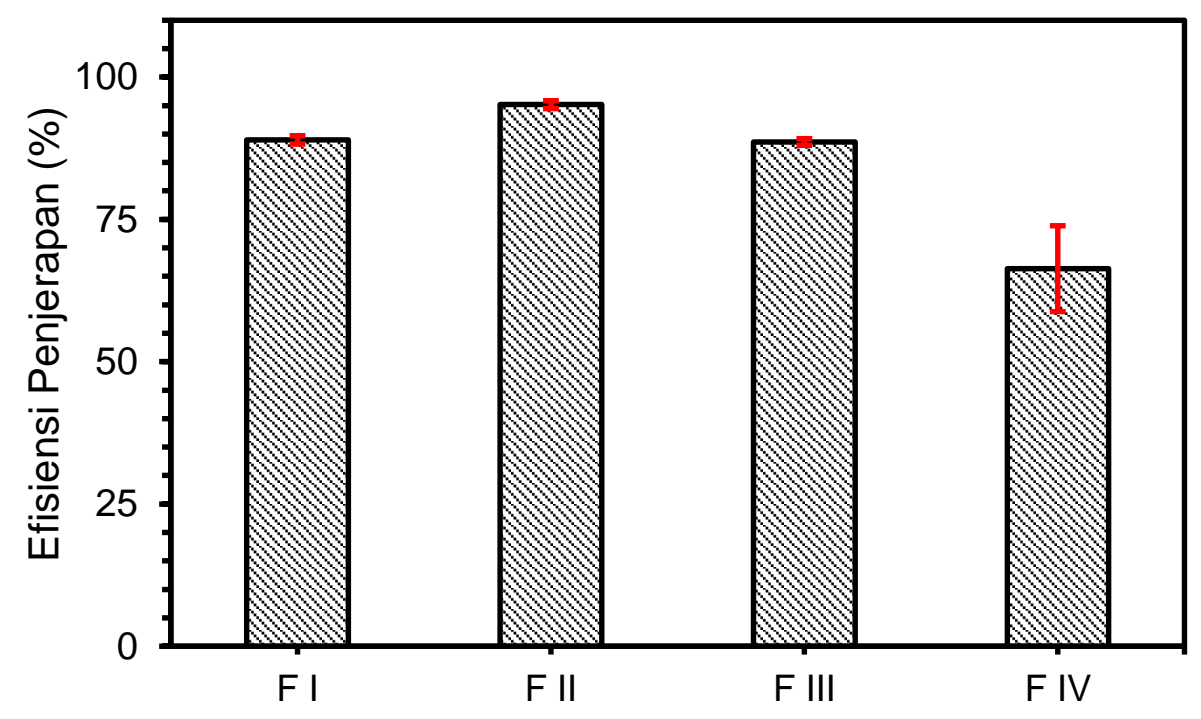

Gambar 4. Pengaruh rasio perbandingan molar fosfolipid dan surfaktan terhadap efisiensi penjerapan. FI (92,5:7,5), FII (90:10); FIII (85:15), dan FIV (80:20).

\subsection{Hasil pembuatan sediaan gel}

Komposisi bahan yang digunakan dalam pembuatan gel meliputi trietanolamin yang berfungsi sebagai neutralizing agent, propilenglikol sebagai humektan, dan Carbopol 934 sebagai basis gel. Carbopol 934 sebagai gelling agent mampu memberikan tampilan estetik, jernih, berkilau, dan mudah dibersihkan dari kulit (Sareen et al., 2011). Karakteristik sediaan gel diuraikan pada Tabel 3.

Tabel 3. Karakteristik sediaan gel naringenin dengan transfersom dan tanpa transfersom. Keterangan: F-A = Formula sediaan gel naringenin dengan transfersom; $\mathrm{F}-\mathrm{B}=$ Formulasi sediaan gel naringenin tanpa transfersom.

\begin{tabular}{ccc}
\hline Parameter & F-A & F-B \\
\hline Organoleptik & Warna: putih & Warna: putih \\
& Bentuk: semisolid & Bentuk: semisolid \\
& Bau: bau khas lipid & Bau: tidak berbau \\
Homogenitas & Homogen & Homogen \\
Viskositas & 260 dPa.s & 203,33 dPa.s \\
Daya lekat & 42,67 detik & 28 detik \\
Daya sebar & $3,60 \pm 0,49 \mathrm{~cm}$ & $4,45 \pm 0,49 \mathrm{~cm}$ \\
pH & $5,25 \pm 0,05$ & $4,77 \pm 0,02$ \\
\hline
\end{tabular}

Sediaan gel kedua formula menghasilkan sediaan yang lembut dengan penampilan warna yang putih. Hasil viskositas, daya sebar dan daya lekat menunjukkan sediaan gel yang memenuhi persyaratan gel secara umum serta nilai $\mathrm{pH}$ sesuai yang dipersyaratkan sesuai dengan pH kulit dalam rentang pH 4,5 - 6,5 (Naibaho, 2013). Perbedaan nilai pH pada F-A dan 
F-B disebabkan karena adanya komponen dapar pada hydrogel yang terinkorporasi dengan trasnfersom narigenin.

\subsection{Uji penetrasi sediaan gel secara in-vitro menggunakan sel difusi Franz}

Uji penetrasi gel naringenin dalam system transfersom (F-A) dan gel tanpa transfersom (F-B) dilakukan dengan menghitung jumlah kumulatif naringenin yang terpenetrasi dan laju obat yang terpenetrasi tiap satuan waktu (fluks). Hasil pengujian kedua formula disajikan pada Gambar 5. Pengujian terhadap jumlah kumulatif penetrasi naringenin kedua formula selama 90 menit (Gambar 5(a)) menunjukkan F-A memberikan jumlah kumulatif yang lebih besar dibandingkan F-B, dengan nilai masing-masing 423,25 $\pm 4,35 \mu \mathrm{g} / \mathrm{cm}^{2}$ dan $60,69 \pm 1,69 \mu \mathrm{g} / \mathrm{cm}^{2}$.

Hasil perhitungan fluks naringenin yang disajikan dalam Gambar 5(b) menunjukkan bahwa pada kondisi steady state memberikan nilai fluks F-A $\left(374,86 \pm 2,9 \mu \mathrm{g} . \mathrm{cm}^{-2} . \mathrm{jam}^{-1}\right)$ lebih tinggi dibandingkan dengan F-B $\left(52,68 \pm 1,13 \mu \mathrm{g} \cdot \mathrm{cm}^{-2} . \mathrm{jam}^{-1}\right)$. Data ini menjelaskan bahwa laju penetrasi F-A lebih cepat dibandingkan dengan F-B dan analisa statisitik menunjukkan terdapat perbedaan yang signifikan. Kemampuan F-A yang lebih baik ini karena sifat deformabilitasnya yang meningkat pada sistem transfersom yang berperan sebagai penetration enhancer sehingga mampu membawa zat aktif naringenin efektif terpenetrasi melewati membran selofan.

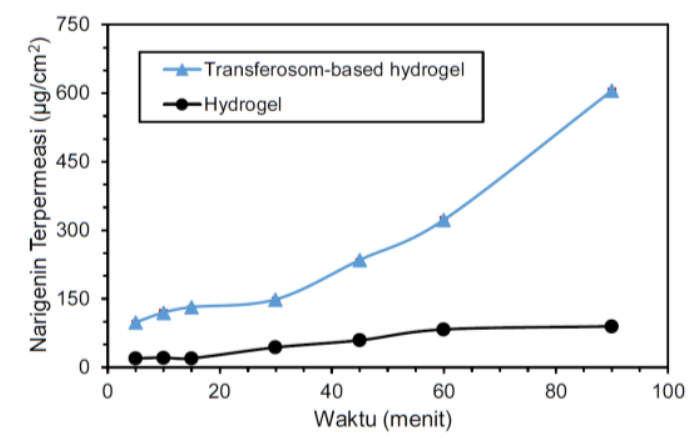

a

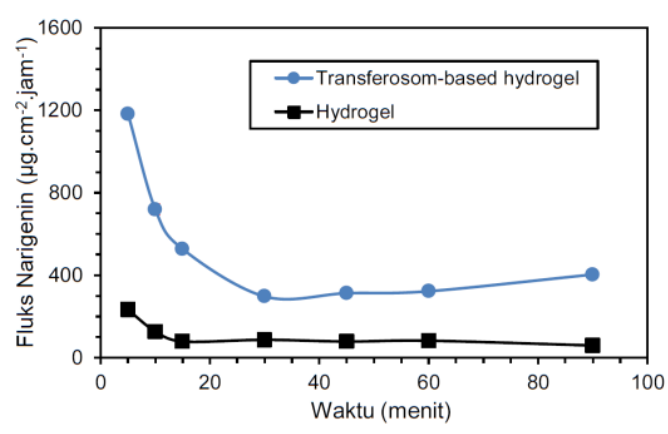

b

Gambar 5. Pengaruh system pembawa berbasis transfersome terhadap jumlah narigenin yang terpemeasi (a) dan fluks narigenin (b).

\section{Kesimpulan}

Karakteristik sistem transfersom naringenin dipengaruhi dari kombinasi perbandingan molar fosfatidilkolin dan Tween 80. Peningkatan jumlah surfaktan akan menurunkan ukuran partikel dan meningkatnya jumlah fosfatidilkolin akan meningkatkan jumlah obat yang terjerap dalam sistem. Formula dengan perbandingan Phospholipon 90G 85\% dan Tween $8015 \%$ merupakan formula terpilih dengan ukuran dan indeks polidispersi partikel masing-masing

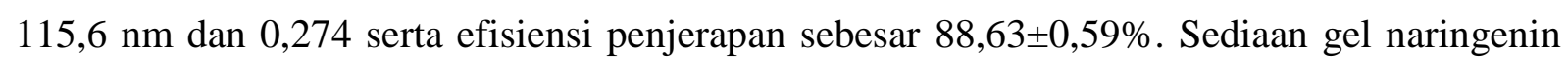
transfersom memberikan nilai jumlah kumulatif dan laju penetrasi 7 kali lebih besar dibandingkan gel naringenin tanpa transfersom. 


\section{Ucapan Terimakasih}

Terima kasih penulis sampaikan kepada Lipoid GmbH Jerman yang telah membantu dalam menyediakan bahan Phospholipon 90G dan Lubrizol Corporation Indonesia yang telah membantu dalam menyediakan bahan Carbopol-934 serta PT. DKSH Indonesia yang telah membantu dalam pengujian ukuran partikel dan indeks polidispersi.

\section{Deklarasi Konflik Kepentingan}

Semua penulis menyatakan tidak ada konflik kepentingan terhadap naskah ini.

\section{Daftar Pustaka}

Aisiyah, S., Harjanti, R., dan Nopiyanti, V. (2019). Pengaruh Panjang Rantai Karbon Lipid Padat Terhadap Karakteristik Nanostructured Lipid Carrier Resveratrol. Journal of Pharmaceutical Science and Clinical Research, 2, 69-81.

Andini, S., Jufri, M., dan Djajadisastra, J. (2016). Formulasi Dan Uji Penetrasi Sediaan Gel Transfersom Yang Mengandung Kojyl 3 Amino Propil Fosfat Sebagai Pencerah Kulit. Indonesian Pharmaceutical Journal, 6(2), 129-136.

Cevc, G., dan Blume, G. (1992). Lipid vesicles penetrate into intact skin owing to the transdermal osmotic gradients and hydration force. Biochimica et Biophysica Acta (BBA)Biomembranes, 1104(1), 226-232.

Choi M.J, dan Maibach H.I, (2005). Elastic vesicles as topical/transderma drug delivery systems. International Journal of Cosmetic Science, 27,211-221.

El Zaafarany, G. M., Awad, G. A., Holayel, S. M., dan Mortada, N. D. (2010). Role of edge activators and surface charge in developing ultradeformable vesicles with enhanced skin delivery. International journal of pharmaceutics, 397(1-2), 164-172.

Fitri, D., Kiromah N.Y.W., Widiastuti. T.C. (2020). Formulasi Dan Karakterisasi Nanopartikel Ekstrak Etanol Daun Salam (Syzygium polyanthum) Pada Berbagai Variasi Komposisi Kitosan Dengan Metode Gelasi Ionik. Journal of Pharmaceutical Science and Clinical Research, 1, 61-69.

Hasani, F., Pezeshki, A., dan Hamishehkar, H. (2015). Effect of surfactant and oil type on size droplets of betacarotene-bearing nanoemulsions. Int J Curr Microbiol App Sci, 4(9), 146155.

Ismail, I., Leboe, D. W., dan Syaputri, N. E. (2018). Pengaruh Perbandingan Konsentrasi Tween 80 dan Fosfatidilkolin terhadap Karakteristik Transfersom Asam Askorbat. ad-Dawaa' Journal of Pharmaceutical Sciences, 1(2).

Joshi, R., Kulkarni, Y. A., dan Wairkar, S. (2018). Pharmacokinetic, pharmacodynamic and formulations aspects of Naringenin: an update. Life sciences, 215, 43-56.

Nagula, R. L., dan Wairkar, S. (2020). Cellulose microsponges based gel of naringenin for atopic dermatitis: Design, optimization, in vitro and in vivo investigation. International Journal of Biological Macromolecules, 164, 717-725.

Naibaho, O. H., Yamlean, P. V., dan Wiyono, W. (2013). Pengaruh basis salep terhadap formulasi sediaan salep ekstrak daun kemangi (Ocimum sanctum L.) pada kulit punggung kelinci yang dibuat infeksi Staphylococcus aureus. Pharmacon, 2(2).

Pannu, A., Goyal, R. K., Ojha, S., dan Nandave, M. (2019). Naringenin: A Promising Flavonoid for Herbal Treatment of Rheumatoid Arthritis and Associated Inflammatory Disorders. In. Bioactive Food as Dietary Interventions for Arthritis and Related Inflammatory Diseases. Cambridge : Academic Press.

Parhi, R., P. dan Suresh. (2010). Production of Solid Lipid Nanoparticles-Drug Loading and Release Mechanism. Journal of Chemical and Pharmaceutical Research 2:211-227. 
Salehi, B., Fokou, P. V. T., Sharifi-Rad, M., Zucca, P., Pezzani, R., Martins, N., dan SharifiRad, J. (2019). The therapeutic potential of naringenin: a review of clinical trials. Pharmaceuticals, 12(1), 11.

Saraf, S., Jeswani, G., Kaur, C. D., dan Saraf, S. (2011). Development of novel herbal cosmetic cream with Curcuma longa extract loaded transfersomes for antiwrinkle effect. African journal of pharmacy and pharmacology, 5(8), 1054-1062.

Sareen, R., Kumar, S., dan D Gupta, G. (2011). Meloxicam carbopol-based gels: characterization and evaluation.Current Drug Delivery, 8(4), 407-415.

Shilakari, G., Singh, D., dan Asthana, A. (2013). Novel vesicular carriers for topical drug delivery and their application's. International Journal of Pharmaceutical Sciences Review and Research, 21(1), 77-86.

Walve JR, Bakliwal SR, Rane BR, dan Pawar SP. (2011). Transferosome: surrogated carriers for transdermal drug delivery system. Int J Appl Biol Pharm, 2(1):204-213.

\section{(c) (1) ()

